There would have been an inevitable delay before grouped blood arrived. The correction of hypovolaemia was paramount if this girl's chance of survival were to be maximised.

\footnotetext{
1 Mandell GL, Gordon-Douglas R, Bennett JE. Infectious mononucleosis. In: Mandell GL, Gordon-Douglas R, mononucleosis. In: Mandell GL, Gordon-Douglas $\mathrm{R}$, Bennett JE, eds. Principles and practice of infectiou
London: Churchill Livingstone, 1990: 1176.
}

2 Hoagland RJ, Henson HM. Splenic rupture in infectious mononucleosis. Ann Intern Med 1957;46:1 184-91.

3 Redmond $\mathrm{AD}$, Redmond CA, Jones JM, Hillier V. The significance of patient appearance in predicting severity of injury. Injury 1994;25:81-2.

4 Advanced Life Support Working Party of the European Resuscitation Council. Guidelines for advanced life support. Resuscitation 1992;24:111-21.

5 Chamberlain DA Lignocaine and bretylium as adjuncts to electrical defibrillation. Resuscitation 1991;22:153-7.

6 Paediatric Life Support Working Party of the European

Resuscitation Council. Guidelines for paediatric life Resuscitation Council. Guidelines
support. BMF 1994;308: 1349-55.

\title{
Aspiration pneumonia in a mentally handicapped patient due to a foreign body impacted in the pharynx: a near fatal outcome
}

\author{
S Asgarali, V Nandapalan, D Phillips, O Osunuga
}

ENT Department, Walton Hospital, Liverpool S Asgarali

ENT Department, Royal Liverpool Hospital,

Liverpool

V Nandapalan

ENT Department,

University of

Liverpool,

Liverpool

D Phillips

Correspondence to:

Mr S Asgarali,

ENT Department

Royal Liverpool Hospital, Prescot Street

Liverpool L7 8XP

Accepted for publication 20 February 1995

\begin{abstract}
A case is reported of a mentally handicapped women with dysphagia caused by a foreign body impacted in the pharynx. The case illustrates a potential pitfall in the management of patients who are unable to communicate either verbally or in writing and who present with acute dysphagia.

(f Accid Emerg Med 1996;13:291)
\end{abstract}

Key terms: dysphagia; pharyngeal foreign body; mental handicap

We report a potential pitfall in the management of patients who are unable to communicate either verbally or in writing and who present with acute dysphagia.

\section{Case report}

An 18 year old mentally handicapped and epileptic female presented to the accident and emergency ( $A \& E$ ) department with a one day history of dysphagia. She was unable to communicate any of her symptoms. There was no drooling of saliva. Examination of her mouth and oropharynx did not reveal any foreign body. Indirect laryngoscopy was not possible and a lateral soft tissue neck $x$ ray was considered to be normal. She was given a glass of water and took sips comfortably. She was then discharged home.

Two days later she became pyrexial with complete dysphagia, vomiting, and dyspnoea. She reattended the A\&E department. Clinical examination and chest $x$ ray were suggestive of pneumonia and she was admitted to the medical ward with a diagnosis of an aspiration pneumonia.
Despite intravenous antibiotics and oxygen, her condition deteriorated over the following 24 hours. An ENT opinion was requested. A fibreoptic nasoendoscope was not tolerated, but a repeat lateral soft tissue neck $x$ ray showed a significant increase in the width of the prevertebral space. Under general anaesthesia, a piece of wooden jigsaw puzzle measuring $55 \times 48 \mathrm{~mm}$ was removed from the hypopharynx.

The patient's condition improved on intravenous antibiotics and chest physiotherapy and she was discharged home one week later.

\section{Discussion}

In patients who are able to give a history and communicate symptoms, and who are able to cooperate with a full examination, the diagnosis of a foreign body impacted in the throat is seldom difficult. However, in patients unable to communicate and who present with dysphagia or aspiration, doctors working in A\&E and ENT departments need to maintain a high index of suspicion of a possible foreign body impacted in the pharynx or upper oesophagus. $^{1-3}$

1 Le Frock JL, Clark TS, Davies B, et al. Aspiration pneumonia: a ten year review. Am f Surg 1979; 45:305-13.

2 Wilfred P. Suspected foreign body on the lateral neck radiograph - pitfalls in interpretation. Radiogr Today radiograph - pitfalls in

3 Huxley EJ, Viroslaw J, Gray WR, Pierce AK. Pharyngeal aspiration in normal adults and patients with depressed consciousness. Am $\mathcal{F}$ Med 1978;64:564-8. 